\title{
In vitro cytotoxicity and genotoxicity of composite mixtures of natural rubber and leather residues used for textile applications
}

Toxicology and Industrial Health 2017, Vol. 33(6) 478-486 (C) The Author(s) 2016 Reprints and permissions: sagepub.co.uk/journalsPermissions.nav DOI: $10.1177 / 0748233716674398$ journals.sagepub.com/home/tih (A)AGE

\author{
Dalita GSM Cavalcante, Andressa S Gomes, \\ Elton AP dos Reis, Caroline S Danna, \\ Leandra E Kerche - Silva, Eidi Yoshihara and Aldo E Job
}

\begin{abstract}
A novel composite material has been developed from natural rubber and leather waste, and a corresponding patent has been filed. This new material may be incorporated into textile and footwear products. However, as leather waste contains chromium, the biocompatibility of this new material and its safety for use in humans must be investigated. The aim of the present study was to investigate the presence of chromium in this new material, determine the amount of each form of chromium present (trivalent or hexavalent), and evaluate the potential cytotoxic and genotoxic effects of the novel composite in two cell lines. The cellular viability was quantified using the MTT3-(4,5-dimethylthiazol-2-yl)2,5-diphenyltetrazolium bromide reduction method and neutral red uptake assay, and genotoxic damage was analyzed using the comet assay. Our findings indicated that the extracts obtained from the composite were severely cytotoxic to both cell lines tested, and additionally highly genotoxic to MRC-5 cells. These biological responses do not appear to be attributable to the presence of chromium, as the trivalent form was predominantly found to be present in the extracts, indicating that hexavalent chromium is not formed during the production of the novel composite. The incorporation of this new material in applications that do not involve direct contact with the human skin is thus indicated, and it is suggested that the chain of production of this material be studied in order to improve its biocompatibility so that it may safely be used in the textile and footwear industries.
\end{abstract}

\section{Keywords}

Chromium, natural rubber, biocompatibility, cell line, leather

\section{Introduction}

Leather shavings are generated when the thickness and fibrillar structure of leather are adjusted during production. These shavings contain chromium from the tanning process and constitute a large proportion of the solid residues generated during leather production (Gomes et al., 2010; Liu et al., 2016; Pati et al., 2014). According to European Union's Directive on Integrated Pollution Prevention and Control (IPPC) (2013), for each ton of leather produced, $225 \mathrm{~kg}$ of tanned residue, including leather shavings, is generated, causing a major environmental impact. Several methods are being developed to utilize the leather shavings produced during industrial activities, with minimal environmental impact (Pacheco, 2005; Priebe et al, 2016). Accordingly, a composite has been developed from a mixture of leather shavings and natural rubber (NR) for use in activities such as partitioning of wall, floors, shoe heels, and car bumpers. In addition to these applications, this composite could be used to manufacture products for the textile and footwear industries such as boots, gloves, and bags.

Faculty of Science and Technology, Department of Physics, Chemistry and Biology, UNESP, Presidente Prudente, SP, Brazil

\section{Corresponding author:}

Aldo E Job, Department of Physics, Chemistry and Biology, Faculty of Science and Technology, UNESP, CP 467, CEP 19060-080, Presidente Prudente, SP, Brazil.

Email: job@fct.unesp.br 


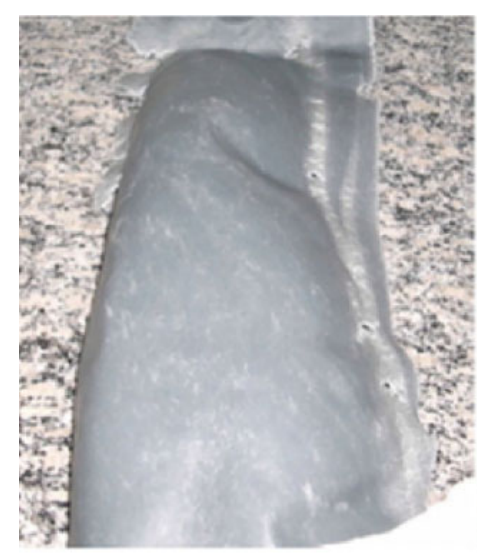

(a)

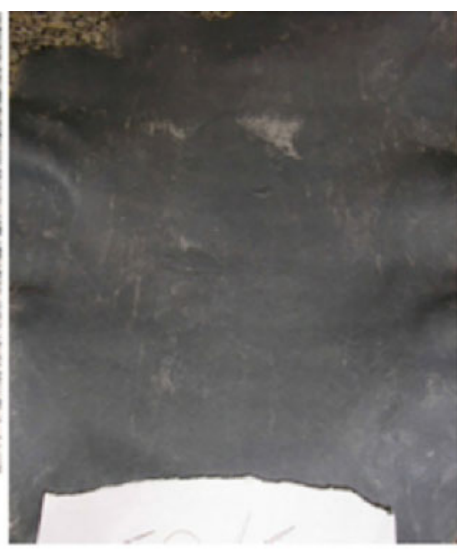

(b)

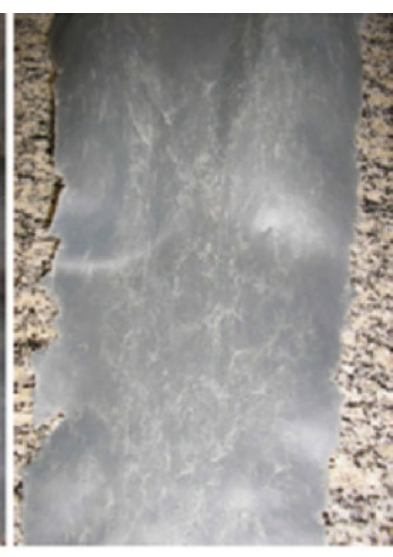

(c)

Figure I. NR/leather waste composite: E40 (a), E50 (b), and E60 (c), obtained after adding vulcanization activators and accelerators via a hot pressing method (Reis, 20l0). NR: natural rubber.

However, the new composite structure contains chromium that originates from the leather shavings utilized in its production (Cabeza et al., 1998; Chaudhary and Pati, 2016). The trivalent form of chromium is an important trace element for normal physiological functions such as the regulation of blood glucose levels (Abraham et al., 1992; Nielsen 2014). Trivalent chromium could be converted into hexavalent chromium, which is more toxic than the trivalent form and a potential carcinogen and irritant to human skin (Saha et al., 2011; Young et al, 2015). As the novel chromium-containing material is meant for incorporation into textiles and footwear, it is expected that it may come into direct contact with human skin. Therefore, the potential effects of this new material in humans must be assessed. Toxicity tests using cell lines are important tools for assessing the biocompatibility of a material, and it is possible to perform an initial toxicity screening to determine alterations that occur at the cellular level (Chiellini, 2006; Pizzoferrato et al., 1994; Swetha et al., 2015). For the composite material in particular, it is of paramount importance to test for genotoxicity in addition to performing cytotoxicity tests, as hexavalent chromium causes DNA damage with potential carcinogenic effects (Mishra and Bharagava, 2016; Nickens et al., 2010).

Therefore, the aim of the present study was to evaluate the in vitro cytotoxicity and genotoxicity of the novel composite consisting of NR and leather residues and determine whether this material may be safely incorporated into textiles and footwear for human use.

\section{Materials and methods}

\section{Cell lines}

The cell lines used in this study were CHO-K1 (Chinese hamster ovarian cells) and MRC-5 (human fetal lung fibroblasts). Cells were cultured in $10 \mathrm{~mL}$ Dulbecco's Modified Eagle Medium/F10 (DMEM/ F10) (Sigma, Saint Louis, United States) supplemented with $10 \%$ fetal bovine serum in cell culture flasks with $25-\mathrm{cm}^{2}$ growth areas and maintained in an incubator with $5 \% \mathrm{CO}_{2}$ at $37^{\circ} \mathrm{C}$.

\section{Preparation of extracts}

The present composite is a mixture of NR and solid residues produced during leather tanning with chromium $(\mathrm{ReC})$. We examined three different proportions of NR and ReC: for every $100 \mathrm{~g} \mathrm{NR}, 40 \mathrm{~g}$ (E40), $50 \mathrm{~g}$ (E50), or $60 \mathrm{~g}$ (E60) ReC was added. The latex used to manufacture NR was collected from rubber trees (Hevea brasiliensis RRIM 600 clone) and stabilized using ammonia. For the vulcanization of NR, we used activators (stearic acid, zinc oxide, and 2-mercaptobenzimidazole zinc salt) and vulcanization accelerators (sulfur, dibenzothiazyl disulfide, and tetramethylthiuram disulfide). A hot pressing method was used to prepare the $\mathrm{NR} / \mathrm{ReC}$ composites (Figure 1).

Liquid extracts of the composites (E40, E50, and E60) were obtained following ASTM F619 (2014) standards. The composite sample was crushed into pieces, mixed with an extraction solution (phosphate-buffered saline (PBS), $\mathrm{pH}$ 7.4) at a ratio 
of $0.2 \mathrm{~g} / \mathrm{mL}$, and maintained under these conditions for $24 \mathrm{~h}$ without agitation. Thereafter, the solid pieces of composite material were removed, and the liquid extracts were used in subsequent analyses. A portion of the solution was set aside for quantification of metal content via inductively coupled plasma optical emission spectrometry (ICP-OES) and analysis by ultraviolet/visible (UV/Vis) spectrophotometry. The remainder was filtered, $\mathrm{pH}$ adjusted to 7.4 with sodium hydroxide $(\mathrm{NaOH})$, and used to carry out biological assays. This solution was considered the undiluted extract $(100 \%)$.

\section{Characterization of extracts by ICP-OES}

ICP-OES was used to quantify the following metals: total chromium, hexavalent chromium, aluminum, arsenic, barium, cadmium, lead, and copper. The samples were subjected to acid digestion using concentrated nitric acid followed by ICP-OES quantification using an Optima 8000 ICP-OES spectrometer (PerkinElmer, Waltham, United States).

\section{Characterization of extracts by UV/Vis spectrophotometry}

The extracts were analyzed using a UV/Vis spectrophotometer (UV-1800, Shimadzu, Kyoto, Japan) in quartz cuvettes ranging from $200 \mathrm{~nm}$ to $1000 \mathrm{~nm}$ in size with PBS as a reference (blank). As a double-beam spectrophotometer was used, the absorbance spectra for the extracts were obtained without any interference from the absorbance of the reference solution.

\section{Exposure protocol}

For the MTT assay, the cells were seeded in a 24-well plate at a density of $1.0 \times 10^{5}$ cells per well. The cells were exposed to $100 \mu \mathrm{L}$ of various dilutions of E40, E50, and E60 or to PBS as negative control (CTR) for $24 \mathrm{~h}$. The dilutions $(5,10,20,40,60$, and $80 \%)$ were obtained from undiluted extracts $(100 \%)$ using PBS as the diluent. An equal amount of culture medium $(100 \mu \mathrm{L})$ was added to each well. For the neutral red uptake assay, the cells were seeded in a 24-well plate at a density of $1.0 \times 10^{5}$ cells per well and incubated at $37^{\circ} \mathrm{C}$ for $24 \mathrm{~h}$ with $100 \mu \mathrm{L}$ PBS (CTR) or E40, E50, and E60 extracts (100\%). The same amount of culture medium $(100 \mu \mathrm{L})$ was added to all wells. For the alkaline version of the comet assay, cells were seeded at a density of $1.0 \times 10^{5}$ cells in cell culture flasks with $12.5-\mathrm{cm}^{2}$ growth areas. Cells were treated for $24 \mathrm{~h}$ with
$1 \mathrm{~mL}$ PBS (CTR) or E40, E50, and E60 (40\%). A positive control (PC) was also prepared using $1 \mathrm{mM}$ methyl methanesulfonate (MMS). The choice of dilution for the comet assay was based on the recommendation that doses decreasing cellular viability by more than $30 \%$ be avoided (Anderson et al., 1998; Henderson et al., 1998; Klungsupya et al., 2015; Tice et al., 2000).

\section{Cytotoxicity assays}

The cytotoxic potential of extracts was assessed using the MTT reduction method (Mosmann, 1983) and neutral red uptake assay. For the MTT reduction method, $0.3 \mathrm{mg} / \mathrm{mL}$ MTT solution was added after an exposure period of $24 \mathrm{~h}$, and cells were incubated at $37^{\circ} \mathrm{C}$ for an additional $4 \mathrm{~h}$. Thereafter, the culture medium was removed, and dimethyl sulfoxide (DMSO) was added. The absorbance of each sample at $492 \mathrm{~nm}$ was determined using a microplate reader. The absorbance of the CTR was considered to represent $100 \%$ cell viability (CV). The CV of the other samples was determined using the following formula: $\mathrm{CVE}=[(\mathrm{AE}-\mathrm{AB}) /(\mathrm{ACTR}-\mathrm{AB})] \times 100$, where $\mathrm{CVE}=\mathrm{CV}$ of cells exposed to the extract, $\mathrm{AE}=$ absorbance of cells exposed to the extract, ACTR = absorbance of cells exposed to PBS, and $\mathrm{AB}=$ absorbance of the blank (well containing culture medium only). For the neutral red uptake assay, neutral red dye (NRd) was added following experimental treatment, and cells were incubated at $37^{\circ} \mathrm{C}$ for a further $3 \mathrm{~h}$. Following exposure to NRd, this solution was replaced with $0.5 \%$ formaldehyde in $1 \%$ calcium chloride for a maximum of $2 \mathrm{~min}$. Subsequently, an acidic ethanol solution (1\% acetic acid in $50 \%$ ethanol) was added, and the contents of all wells were homogenized after $15 \mathrm{~min}$. The absorbance of each sample at $550 \mathrm{~nm}$ was determined using UV/Vis spectroscopy, and the viability was calculated similarly to that for the MTT reduction assay.

\section{Comet assay}

The levels of DNA damage in cells exposed to both extracts were evaluated by the comet assay. Following exposure to the extracts, the adherent cells were trypsinized, and fetal bovine serum was added. The resulting cell suspension was used to prepare slides for the comet assay as described by Singh et al. (1988) with slight modifications. The samples were mixed with low-melting-point agarose $(0.5 \%)$ and divided into two glass slides previously coated with a layer of normal-melting-point agarose (1.5\%), covered with 
Table I. Quantification of the concentration of metals found in the extracts and PBS using ICP-OES.

\begin{tabular}{lccccc}
\hline & Detection limit $(\mathrm{mg} / \mathrm{L})$ & PBS $(\mathrm{mg} / \mathrm{L})$ & $\mathrm{E} 40(\mathrm{mg} / \mathrm{L})$ & $\mathrm{E} 50(\mathrm{mg} / \mathrm{L})$ & $\mathrm{E} 60(\mathrm{mg} / \mathrm{L})$ \\
\hline Aluminum & 0.029 & $<0.029$ & $1.035^{\mathrm{a}}$ & $1.361^{\mathrm{a}}$ & $0.395^{\mathrm{a}}$ \\
Arsenic & 0.008 & $<0.008$ & $<0.008$ & $<0.008$ & $<0.008$ \\
Barium & 0.008 & 0.009 & 0.009 & $0.01 \mathrm{l}$ & $0.020^{\mathrm{a}}$ \\
Cadmium & 0.005 & $<0.005$ & $<0.005$ & $<0.005$ & $<0.005$ \\
Lead & 0.008 & $<0.008$ & $<0.008$ & $<0.008$ & $<0.008$ \\
Copper & 0.018 & $<0.018$ & $<0.018$ & $0.046^{\mathrm{a}}$ & $<0.018$ \\
Total chromium & 0.010 & $<0.010$ & $0.069^{\mathrm{a}}$ & $0.087^{\mathrm{a}}$ & $0.153^{\mathrm{a}}$ \\
Hexavalent chromium & 0.050 & $<0.050$ & $<0.050$ & $<0.050$ & $<0.050$ \\
\hline
\end{tabular}

PBS: phosphate-buffered saline; ICP-OES: inductively coupled plasma optical emission spectrometry.

${ }^{a}$ Significant difference compared with control PBS.

coverslips, and incubated for $30 \mathrm{~min}$ at $4^{\circ} \mathrm{C}$ to solidify the agarose. Thereafter, the slides were placed in lysis solution $(2.5 \mathrm{M} \mathrm{NaCl} ; 100 \mathrm{mM}$ Ethylenediamine tetraacetic acid (EDTA); $10 \mathrm{mM}$ Tris, $1 \%$ Triton $\mathrm{X}-100$; and $10 \%$ DMSO) for $1 \mathrm{~h}$. After the lysis step, all slides were transferred to an electrophoresis tank containing freshly prepared cold alkaline buffer (1 mM EDTA and $300 \mathrm{mM} \mathrm{NaOH}, \mathrm{pH}>13)$. The slides were incubated for 30 min to unwind DNA, and electrophoresis was performed at $25 \mathrm{~V}$ and $300 \mathrm{~mA}$ for $20 \mathrm{~min}$. Thereafter, they were placed in a neutralizing solution ( 0.4 $\mathrm{M}$ Tris, $\mathrm{pH}$ 7.5) and fixed with absolute ethanol. The slides were then stained with DAPI 4',6-Diamidine2'-phenylindole dihydrochloride solution $(1 \mathrm{mg} / \mathrm{mL}$ $D A P I$ in $\mathrm{H}_{2} \mathrm{O}$ ) and visualized by fluorescence microscopy. One hundred cells were counted per slide, and DNA damage was classified into four categories according to the migration of DNA fragments as described by Kobayashi et al. (1995).

\section{Statistical analysis}

The results were compared by parametric analysis of variance using the Student-Newman-Keuls method or the nonparametric Kruskal-Wallis test, in accordance with the distribution of the data (normality and homogeneity of variance). A value of $p<0.05$ was considered significant, and the results were expressed as mean $\pm \mathrm{SD}$.

\section{Results}

\section{Characterization of extracts}

The quantification of metals by ICP-OES indicated that the total amounts of chromium and aluminum in the extracts were higher than those in the PBS control; however, the concentration of barium was higher only in the E60 extract than in the PBS control. For both PBS and the extracts (except E50), the concentrations of arsenic, cadmium, lead, hexavalent chromium, and copper were below the quantification limits of the instrument, which are $0.008,0.005$, $0.008,0.018$, and $0.05 \mathrm{mg} / \mathrm{L}$, respectively (Table 1 ).

Analysis of the extract absorption spectra by UV/ Vis spectrophotometry indicated an absorption band between $300 \mathrm{~nm}$ and $350 \mathrm{~nm}$ in all three extracts; however, its intensity was weakest for the E40 extract (Figure 2).

\section{CV based on the MTT assay}

The results indicate that the viability of CHO-K1 cells exposed to $5 \%$ and $10 \%$ dilutions of E40, E50, and E60 extracts (Figure 3(a)) was not significantly different from that of the CTR. At dilutions greater than $20 \%$, significant differences in viability were found between cells exposed to the extracts and those exposed to the CTR. Dilutions of 60, 80, and $100 \%$ for the E40, E50, and E60 extracts were severely cytotoxic. For MRC-5 cells (Figure 3(b)), there was no statistically significant difference in the $\mathrm{CV}$ of cells exposed to $5 \%$ dilution of both extracts and those exposed to the CTR. At concentrations $\geq 10 \%$ for the E40, E50, and E60 extracts, significant differences in $\mathrm{CV}$ were found between cells exposed to extracts and those exposed to the CTR. Cells exposed to dilutions $\geq 60 \%$ exhibited higher mortality than that exhibited by the cells exposed to the CTR.

\section{$\mathrm{CV}$ based on neutral red uptake assay}

The viabilities of the CHO-K1 and MRC-5 cell lines upon exposure to the E40, E50, and E60 extracts were significantly lower (less than 20\%) than that for the respective CTR (Figure 4). 


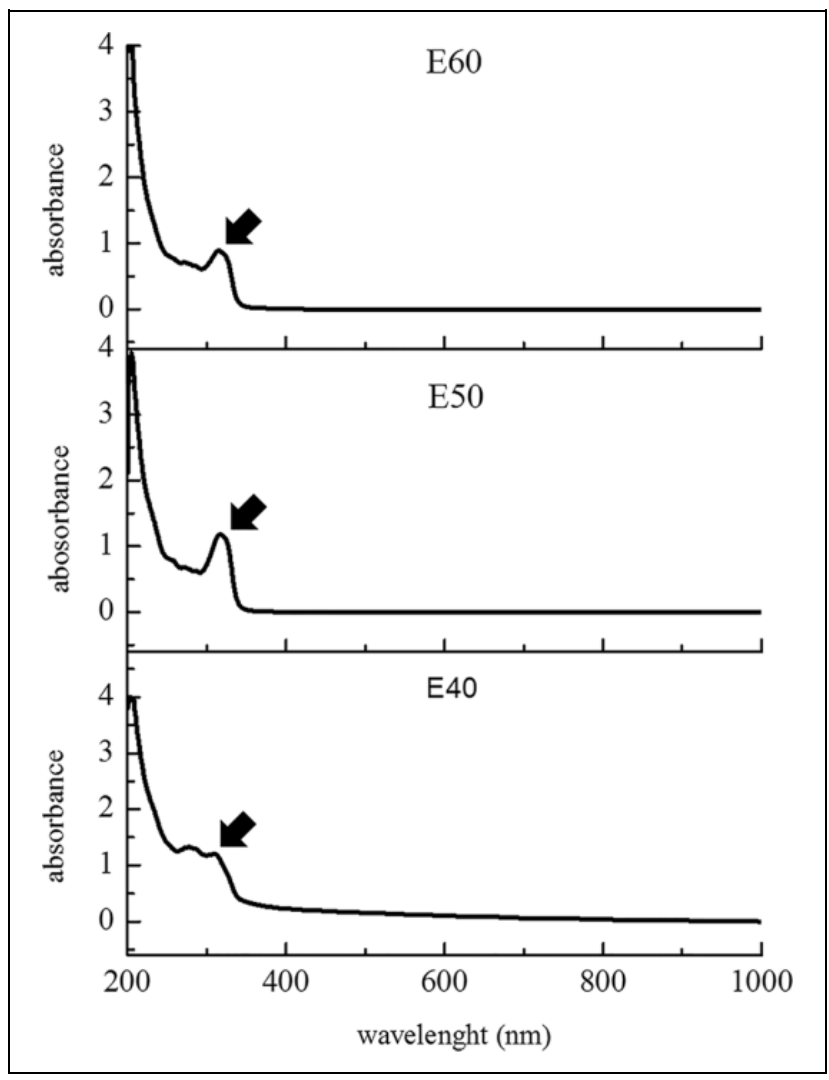

Figure 2. Absorption spectra of extracts made by UV-Vis spectrophotometry. Arrows indicate absorption band found for different samples. UV-Vis: ultraviolet-visible.

\section{Comet assay}

The results of the comet assay indicated that no DNA damage had occurred in CHO-K1 cells exposed to $\mathrm{E} 40$, E50, or E60 extracts (diluted to $40 \%$ ) in comparison with the CTR. However, significant DNA damage was found in MRC-5 cells exposed to E50 and E60 (both diluted to 40\%) compared to that in the cells exposed to the CTR. The $1 \mathrm{mM}$ solution of MMS (PC) was highly genotoxic, eliciting a significantly greater degree of DNA damage than that caused by the CTR (Figure 5).

\section{Discussion}

Among numerous methods available for evaluating the cytotoxicity of materials, the MTT and neutral red uptake assays have gained prominence because of their simplicity, rapidity, cost-effectiveness, and reproducibility. The MTT assay is used to assess $\mathrm{CV}$ in terms of mitochondrial activity, whereas the neutral red uptake assay measures the number of viable cells based on their ability to retain dye in their lysosomes (van Meerloo et al., 2011; Repetto et al.,
2008; Tong et al., 2016). In this study, both the MTT and neutral red uptake assays indicated that extracts (at a concentration of $100 \%$ ) from all three versions of the composite exert severe cytotoxic effects in both CHO-K1 and MRC-5 cell lines.

As the undiluted extracts were highly cytotoxic to both cell lines, cells were exposed to various dilutions to determine the dilution of the extract for use in the comet assay. The results of the comet assay indicated that extracts prepared using all three versions of the composite caused a greater degree of DNA damage in the MRC-5 cell culture than that caused by the CTR; however, this effect is not observed in the CHO-K1 cell line. The difference in genotoxicity between the cell lines may be attributable to the cell type-specific sensitivity to the genotoxic agent: The CHO-K1 cell line, which comprises transformed cells, may be more resilient than the MRC-5 cell line, which is obtained by culturing normal fibroblasts (Genies et al., 2013; Lu et al., 2013; Ponzinibbio et al., 2008).

To establish whether these findings were due to chromium exposure, we analyzed the amount of chromium in the three versions of the composite by using ICP-OES. The results indicated the presence of chromium in all the extracts, and the amount of chromium present in the extracts was significantly higher than that in the vehicle, suggesting that chromium is released from the composite into the extraction medium during extract preparation. Establishment of the chromium oxidation state in the extract indicated that any hexavalent chromium in the samples was present at less than $0.05 \mathrm{mg} / \mathrm{L}$. Therefore, the data suggest that most of the chromium present in the extract is in the trivalent form and that there was no observable conversion of trivalent chromium to the hexavalent state during the composite manufacturing process. Trivalent chromium exhibits low cellular penetration and is therefore considered to possess low toxicity (Hininger et al., 2007; Shekhawat et al, 2015). Accordingly, it may be inferred that the high cytotoxicity and genotoxicity of the composite extracts were not related to either oxidized form of chromium.

As it is unlikely that the cytotoxic and genotoxic effects of the extracts were attributable to chromium, we further analyzed the composite to elucidate the reasons for the biological responses observed in the CHO-K1 and MRC-5 cell lines. Quantification of the metal content by ICP-OES revealed that the amount of aluminum in the various extracts was significantly higher than that in the CTR. Reis (2010), the inventor of the present composite, observed aluminum peaks in 


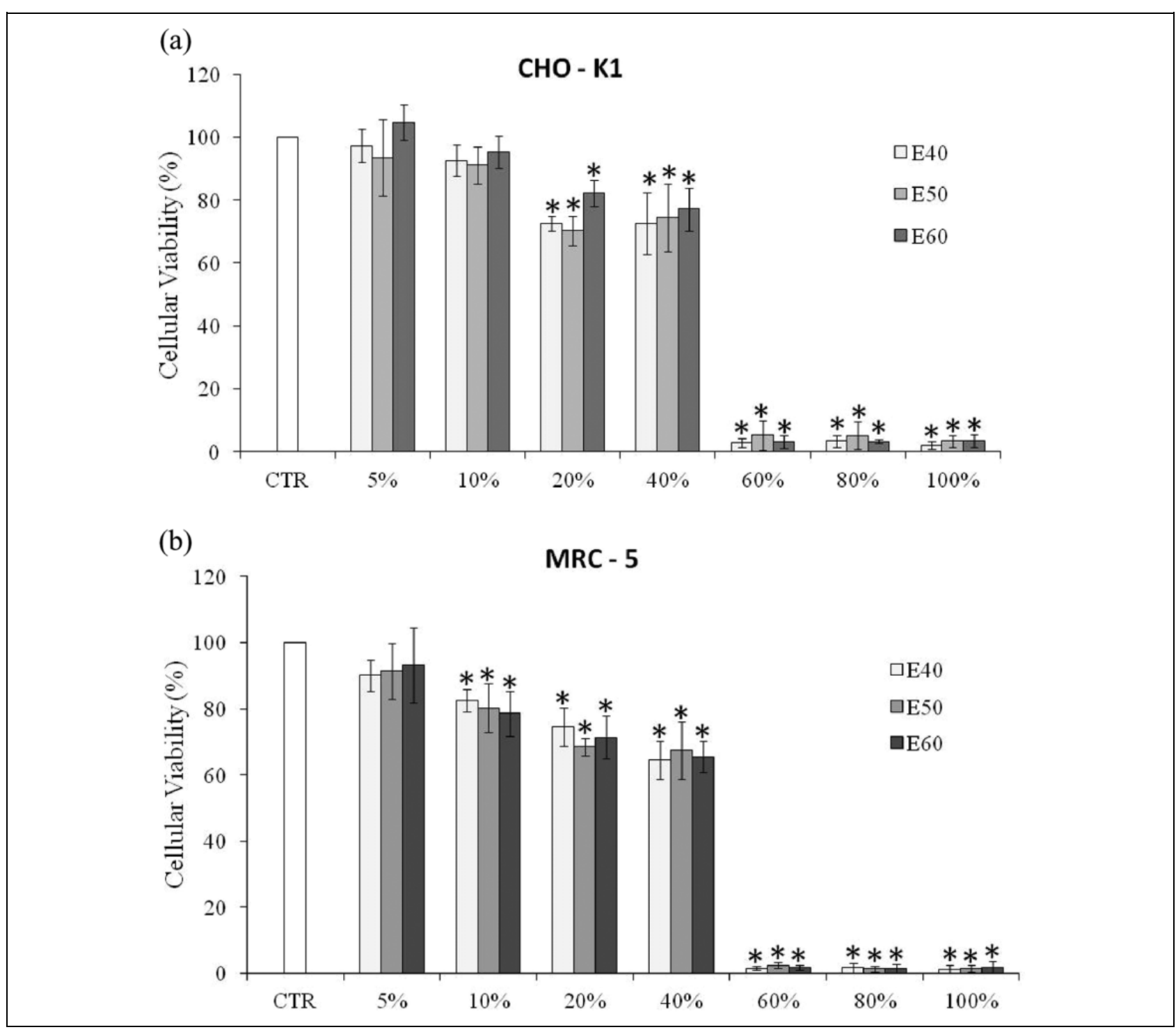

Figure 3. Cell viability (\%) of CHO-KI and MRC-5 exposed to different extracts E40, E50, and E60 at the concentration of $100 \%$ or only the culture medium (CTR) for $24 \mathrm{~h}$, quantified by the neutral red uptake assay. *Significant difference compared with CTR, which was considered $100 \%(p<0.05)$.

the NR spectrum using energy-dispersive X-ray spectroscopy (EDS) and inferred that this metal is derived from other nonrubber constituents that may be found in latex. The cytotoxic and genotoxic effects of aluminum exposure on various biological systems have been described previously (Djouina et al., 2016; D'Souza et al., 2014; García-Medina et al., 2011). It is therefore possible that aluminum present in the extracts contributed to the genotoxic and cytotoxic effects observed herein.

In addition to heavy metals, the activators and accelerators used in vulcanization of the NR during the composite manufacturing process must be considered. Indeed, several previous studies have attributed the toxicity of materials produced from NR latex to the compounds used for latex vulcanization (Campos et al., 1999; Ingre-Khans et al., 2010; Lönnroth, 2005; Roy et al., 2015). Using high-performance liquid chromatography, Abraham et al. (2005) found that the dithiocarbamate vulcanization accelerator was released from the vulcanized material into the physiologically simulated medium. In the present report, a $\mathrm{UV} / \mathrm{V}$ is absorption band between $300 \mathrm{~nm}$ and $350 \mathrm{~nm}$ was detected, which indicates the presence of molecular species in the extracts that were not present in the extractor vessel (PBS). This suggests that at least one compound from the composite was released into the extractor vessel. However, analysis of this type of 


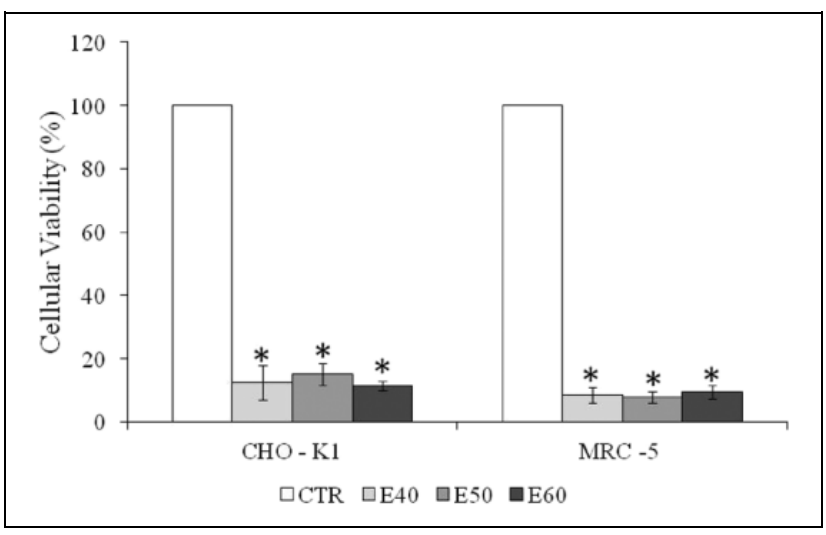

Figure 4. Cell viability (\%) of CHO-KI and MRC-5 exposed to different extracts E40, E50, and E60 at the concentration of $100 \%$ or only the culture medium (CTR) for $24 \mathrm{~h}$, quantified by the neutral red uptake assay. *Significant difference compared with CTR, which was considered $100 \%(p<0.05)$. spectrum does not allow for precise identification of specific substances in mixtures; a combination of other methodologies is required to identify complex mixtures (Milman, 2011). Reis (2010) noted the presence of crystal-like structures on the surface of all the composites and performed EDS studies to conclude that these structures represented atomic sulfur and zinc oxide that had not reacted during the vulcanization process. It is possible that these "crystals" on the surface of the composite material were released into the extract, thereby contributing toward the genotoxic and cytotoxic effects observed in this study.

Based on the above data, we conclude that the extracts obtained from all three versions of the composite were severely cytotoxic to both cell lines tested and highly genotoxic to the MRC-5 cells. These biological responses appear to be unrelated to the presence of chromium metal, as trivalent chromium was

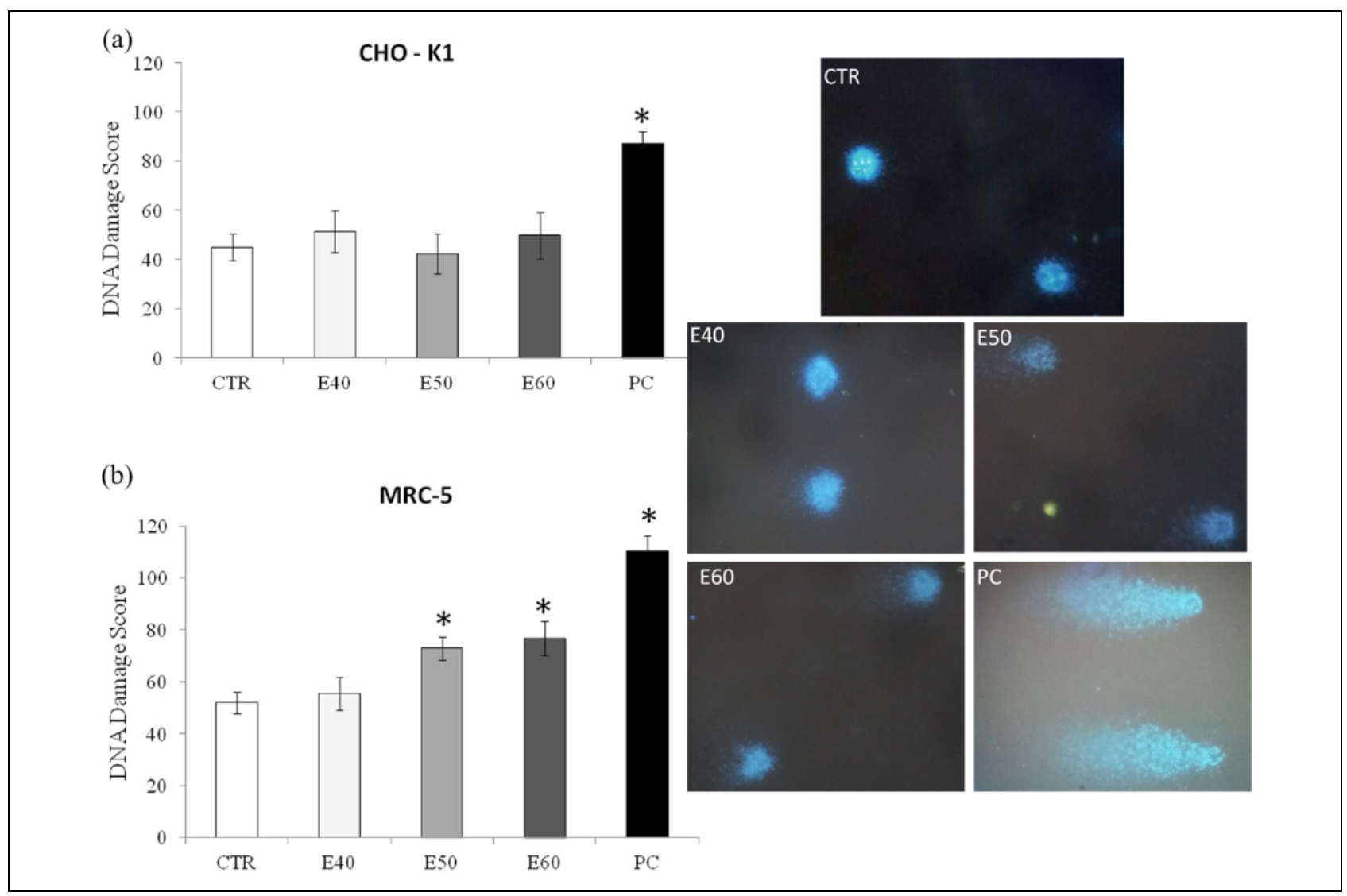

Figure 5. DNA damage in CHO-KI cells (a) and MRC-5 (b) exposed to different extracts E40, E50, and E60 at the concentration of $40 \%$ or just to the culture medium (CTR) for $24 \mathrm{~h}$. PC represents positive control. Comet assay images were included (in different experimental conditions). The bars indicate the average and standard deviation of the vertical lines. *Significant difference compared to the respective negative control (CTR; $p \leq 0.05)$. 
found to be predominantly present in the extracts. This further suggests that hexavalent chromium was not formed during production of the composite. These results support application of the novel composite material for uses that do not involve direct contact with the human skin. We further recommend that the process of composite production be studied in detail to develop a composite structure with improved biocompatibility that can be safely used by the textile and footwear industries.

\section{Declaration of Conflicting Interests}

The author(s) declared no potential conflicts of interest with respect to the research, authorship, and/or publication of this article.

\section{Funding}

The author(s) disclosed receipt of the following financial support for the research, authorship, and/or publication of this article: The authors acknowledge Fundação de Amparo à Pesquisa do Estado de São Paulo (Processo FAPESP 2013/24884-5), for the financial support, and Agência Paulista de Tecnologia de Agronegócios (APTA) for the use of its facilities.

\section{References}

Abraham AS, Brooks BA and Eylath U (1992) The effects of chromium supplementation on serum glucose and lipids in patients with and without non-insulindependent diabetes. Metabolism 41: 768-771.

Abraham EK, Ramesh P, Joseph R, et al. (2005) Release of dithiocarbamates into sweat from natural rubber latex surgical gloves. Rubber Chemistry and Technology 78: 674-681.

Anderson D, Yu T-W and McGregor DB (1998) Comet assay responses as indicators of carcinogenic exposure. Mutagenesis 13: 539-555.

ASTM F619 (2014) Standard practice for extraction of medical plastics. ASTM International, West Conshohocken, PA, 2014.

Cabeza LF, Taylor MM, DiMaio GL, et al. (1998) Processing of leather waste: pilot scale studies on chrome shavings. Isolation of potentially valuable protein products and chromium. Waste Management 18: 211-218.

Campos VE, Hanada S, Higa OZ, et al. (1999) Toxicological evaluation of natural rubber latex film vulcanized with ionizing radiation. 7 General Congress on Nuclear Energy, Brazil. Available at: https://inis.iaea.org/search/ search.aspx?orig_q=RN:30041699.

Chaudhary R and Pati A (2016) Poultry feed based on protein hydrolysate derived from chrome-tanned leather solid waste: creating value from waste. Environmental Science and Pollution Research 23: 8120-8124.

Chiellini F (2006) Perspectives on: in vitro evaluation of biomedical polymers. Journal of Bioactive and Compatible Polymers 21: 257-271.

Djouina M, Esquerre N, Desreumaux P, et al. (2016) Toxicological consequences of experimental exposure to aluminum in human intestinal epithelial cells. Food and Chemical Toxicology 91: 108-116.

D’Souza P, Vijayalaxmi KK and Naik P (2014) Assessment of genotoxicity of aluminium acetate in bone marrow, male germ cells and fetal liver cells of Swiss albino mice. Genetic Toxicology and Environmental Mutagenesis 766: 16-22.

García-Medina S, Razo-Estrada C, Galar-Martínez M, et al. (2011) Genotoxic and cytotoxic effects induced by aluminum in the lymphocytes of the common carp (Cyprinus carpio). Comparative Biochemistry and PhysiologyPart C: Toxicology \& Pharmacology 153: 113-118.

Genies C, Martre A, Lefebvre E, et al. (2013) The extreme variety of genotoxic response to benzo[a]pyrene in three different human cell lines from three different organs. PLoS ONE 8(11): e78356.

Gomes AC, Moraes LCK and Silva MJ (2010) Caracterização de resíduo de curtume para determinação de disposição final. Omnia Exatas 3: 33-40.

Henderson L, Wolfreys A, Fedyk J, et al. (1998) The ability of the Comet assay to discriminate between genotoxins and cytotoxins. Mutagenesis 13: 89-94.

Hininger I, Benaraba R, Osman M, et al. (2007) Safety of trivalent chromium complexes: no evidence for DNA damage in human HaCaT keratinocytes. Free Radical Biology and Medicine 42: 1759-1765.

Ingre-Khans E, Rudén C and Breitholtz M (2010) Chemical risks and consumer products: the toxicity of shoe soles. Ecotoxicology and Environmental Safety 73: 1633-1640.

IPPC Directive (2013) Reference Document for the Tanning of Hides and Skins: Industrial Emissions Directive 2010/75/EU: (Integrated Pollution Prevention and Control). Available at: http://eippcb.jrc.ec.europa.eu/refer ence/tan.html

Klungsupya P, Suthepakul N, Muangman T, et al. (2015) Determination of free radical scavenging, antioxidative DNA damage activities and phytochemical components of active fractions from Lansium domesticum Corr. fruit. Nutrients 7: 6852-6873.

Kobayashi H, Suguyama C, Morikawa Y, et al. (1995) A comparison between manual microscopic analysis and computerized image analysis in the single cell gel electrophoresis. MMS Communications 3: 103-115. 
Liu M, Ma J, Lyu B, et al. (2016) Enhancement of chromium uptake in tanning process of goat garment leather using nanocomposite. Journal of Cleaner Production 133: 487-494.

Lönnroth EC (2005) Toxicity of medical glove materials: a pilot study. International Journal of Occupational Safety and Ergonomics 11: 131-139.

Lu Y, Xu D, Zhou J, Ma Y, et al. (2013) Differential responses to genotoxic agents between induced pluripotent stem cells and tumor cell lines. Journal of Hematology \& Oncology 6: 71.

Milman BL (2011) Chemical Identification and Its Quality Assurance. Germany: Springer.

Mishra S and Bharagava RN (2016) Toxic and genotoxic effects of hexavalent chromium in environment and its bioremediation strategies. Journal of Environmental Science and Health, Part C: Environmental Carcinogenesis and Ecotoxicology 34: 1.

Mosmann T (1983) Rapid colorimetric assay for cellular growth and survival: application to proliferation and cytotoxicity assays. Journal of Immunological Methods 65: 55-63.

Nickens KP, Patierno SR and Ceryak S (2010) Chromium genotoxicity: a double-edged sword. Chemico Biological Interactions 188: 276-288.

Nielsen FH (2014) Should bioactive trace elements not recognized as essential, but with beneficial health effects, have intake recommendations. Journal of Trace Elements in Medicine and Biology 28: 406-408.

Pacheco JWF (2005) Curtumes. São Paulo: CETESB, p. 76.

Pati A, Chaudhary R and Subramani S (2014) A review on management of chrome-tanned leather shavings: a holistic paradigm to combat the environmental issues. Environmental Science and Pollution Research International 21: 11266-11282.

Pizzoferrato A, Ciapetti G, Stea S, et al. (1994) Cell culture methods for testing biocompatibility. Clinical Materials 15: 173-190.

Ponzinibbio MV, Crudeli C, Mira A, et al. (2008) Comparison of the effects of low doses of X-rays in two cell lines. Biocell 32: 134.

Priebe GPS, Kippera E, Gusmão AL, et al. (2016) Anaerobic digestion of chrome-tanned leather waste for biogas production. Journal of Cleaner Production 129: 410-416.
Reis EAP (2010) Preparation and characterization of composites obtained by mixture of natural rubber with scrapes of leather seeking industrial application. Master's Dissertation, Universidade Estadual Paulista “Júlio de Mesquita Filho," Brazil.

Repetto G, del Peso A and Zurita J L (2008) Neutral red uptake assay for the estimation of cell viability/ cytotoxicity. Nature Protocols 3: 1125-1131.

Roy K, Alam MN, Mandal SK, et al. (2015) Preparation of zinc-oxide-free natural rubber nanocomposites using nanostructured magnesium oxide as cure activator. Journal of Applied Polymer Science 132: 42705.

Saha R, Nandi R and Saha B (2011) Sources and toxicity of hexavalent chromium. Journal of Coordination Chemistry 64: 1782-1806.

Shekhawat K, Chatterjee S and Joshi B (2015) Chromium toxicity and its health hazards. International Journal of Advanced Research 3: 167-172.

Singh NP, McCoy MT, Tice RR, et al. (1988) A single technique for quantification of low levels of DNA damage in individual cells. Experimental Cell Research 175: 184-191.

Swetha B, Mathew S, Sreenivasa Murthy BV, et al. (2015) determination of biocompatibility: a review. International Dental \& Medical Journal of Advanced Research 1: $1-6$.

Tice RR, Agurell E, Anderson D, et al. (2000) Single cell gel/comet assay: guidelines for in vitro and in vivo genetic toxicology testing. Environmental and Molecular Mutagenesis 35: 206-221.

Tong J, Wang Y and Lu Y (2016) In vitro evaluation of inorganic and methyl mercury mediated cytotoxic effect on neural cells derived from different animal species. Journal of Environmental Sciences 41: 138-145.

van Meerloo J, Kaspers GJ and Cloos J (2011) Cell sensitivity assays: the MTT assay. Methods in Molecular Biology 731: 237-245.

Young JL, Wise SS, Xie H, et al. (2015) Comparative cytotoxicity and genotoxicity of soluble and particulate hexavalent chromium in human and hawksbill sea turtle (Eretmochelys imbricata) skin cells. Comparative Biochemistry and Physiology Part C: Toxicology \& Pharmacology 178: 145-155. 